[DOI: 10.24214/jecet.A.9.4.68900]

Jaurnal of Environmental Science, Computer Science and Engineering \& Technology

An International Peer Review E-3 Journal of Sciences and Technology

Available online at www.jecet.org

Section A: Environmental Science

Research Article

\title{
Microbial remediation model of fungal in crude oil- contaminated water
}

\author{
Ibekwe, S.E, P.O. Okerentugba and G.C. Okpokwasili \\ Department of Microbiology,University of Port Harcourt, P.M.B. 5323, Port Harcourt,Nigeria
}

Received: 05 October 2020; Revised: 18 October 2020; Accepted: 26 October 2020

\begin{abstract}
Mathematical modeling is important tool in analyzing and understanding complex environmental systems. It is a method of simulating real-life situations with mathematical equations to forecast their future behaviour. Modeling of microbiological parameters was done using SPSS 23 for descriptive statistics while E-view 10 software was used for pooled regression model. Crude oil-contaminated soil from Bodo in Ogoniland was sampled for bioremediation and seven treatments designated $\mathrm{A}$ to $\mathrm{G}$ were setup in triplicates in cells. Five were biostimulated with $\mathrm{NH}_{4} \mathrm{NO}_{3}$ and $\mathrm{KH}_{2} \mathrm{PO}_{4}$ while unamended and heat treated were controls. The bioremediation lasted 56days with $50 \%$ contaminated media amended with $1 \%$ treatment material. The setup was sampled repeatedly at intervals for analysis within study period. EW had highest fungal count for water on day 28. However, FW had the lowest fungal count for water on day 0 . Hydrocarbon utilizing fungal (HUF) count revealed that EW had highest count on day 28. But FW had no growth from day 42 to day 56 . For all treatments on day 0 , total petroleum hydrocarbon (TPH) ranged from 341.96 to $650.98 \mathrm{mg} / \mathrm{L}$. No PAH was detected in water. FW had the highest TPH $(647.88 \mathrm{mg} / \mathrm{L})$ on day 0 while $\mathrm{CW}$ had the lowest TPH (46.36 mg/L) on day 56. In all treatments by day 56 , the TPH was $<61$ $\mathrm{mg} / \mathrm{L}$ and the percentage loss of TPH of various treatments as measured with GC-FID were AW (83\%), BW (88 \%), CW (90\%), DW (89\%), EW (87\%), FW (60\%) and heat treated GW (10\%). However, CW had the highest percentage loss $(90 \%)$ of TPH followed by DW (89\%) and lastly GW (10\%). The following fungal genera were identified: Cadida sp (44.86 \%), Aspergillus sp (14.02 \%), Rhodotorula sp (2.80 \%), Nocardia sp (1.87 \%), Scopulariopsis sp (1.87 \%), Exophiala sp (2.80 \%), Trichophyton sp (2.80\%), Microsporium sp (3.74 \%), Phoma sp (1.87\%) Fonsecaea
\end{abstract}


sp (3.74 \%), Chaetimium sp (3.74\%), Penicillium sp (3.74\%), Cokeromyces sp (1.87 $\%)$. The regression model of microbiological parameters which showed effect of time, TN and TP on fungi (TFC and HUF) and the effect of fungi on TPH and TOC for crude oil-contaminated water. Time and total phosphorous affected TFC positively while total nitrogen affected TFC negatively. A unit increase in time increased TFC by 0.0503 while an increase in total phosphorous increased TFC by 1.0214 . But an increase in total nitrogen decreased TFC by 0.1064 . Time and total phosphorous affected HUF positively while total nitrogen affected HUF negatively. An increase of time and total phosphorous increased HUF by 0.0119 and 0.8568 respectively. But a unit increase in total nitrogen decreased HUF by 0.1264 . HUF affected TOC positively while TFC and time affected TOC negatively. A unit increase in time and TFC decreased TOC while a decrease in TOC increased HUF. Time and TFC affected TPH negatively while HUF affected TPH positively. A unit increase in time and TFC decreased TPH. A decrease in TPH increased HUF. These changes and effects by these mathematical models were statistically significant at $\mathrm{P}-$ value $<0.05$ and $\mathrm{t}$-values. Fvalues implied overall models were statistically significant. These models have established that adjusting of limiting nutrients (nitrogen, phosphorous) is the key to effective and efficient bioremediation of crude oil-contaminated media.

Keywords: bioremediation, mathematical model, nitrogen, phosphorous, TPH, HUF, TFC.

\section{INTRODUCTION}

Mathematical models are tools for understanding complex biological processes as a result of interplay of numerous molecular components. Biochemical reactions often obey nonlinear reaction kinetics i.e. an increase in the amount of the starting material of the reaction does not necessarily lead to a proportional increase in the amount of the reaction product. Mathematical models that take these factors into consideration allow researchers to capture the features of complex biological systems and to understand how biological systems respond to external or internal signals and perturbations, such as different growth, increase in the number of cells due to cell growth and cell division (i.e., proliferation), cell death (i.e., apoptosis), which involve hundred types of molecules ${ }^{[1-3]}$.

Mathematical models employ computer simulations in describing biological systems that generally are too complex to be solved analytically ("manually") and therefore resolved numerically using computers to stimulate the mathematical equations that help predict the response of a biological system. With the availability of computer-based techniques for solving mathematical equations, the response of a biological system to different conditions can be relatively easily simulated in silico once a mathematical model is available $\mathrm{e}^{[4]}$.

The general approach for creating and using mathematical models in biological sciences is similar to the one followed in other scientific disciplines such as physics, the theories and mathematical formulas developed by theoretical biologists on the basis of existing experimental data can be tested by experimentalists and used to predict the behaviour of biological systems under as-yet-unexplored conditions ${ }^{[3.5]}$. Modeling is done to establish whether microbial activity is responsible for direct breakdown of organic contaminants or whether it is employed indirectly to alter geochemical conditions.

Prokaryotes are the most dominant microorganisms in the biosphere. It contains about $4-6 \times 10^{30}$ cells ${ }^{[6]}$. This number is more than all the plant and animal cells combined. Microorganisms are highly 
diverse group of organisms and constitute about $60 \%$ of the earth's biomass ${ }^{[7]}$. In aquatic environments, like oceans, the members of microbial cells has been estimated to be approximately $1.2 \times 10^{29}$, while in terrestrial environments, soil sustains as many as $4-6 \times 10^{30}$ microbial cells ${ }^{[7]}$. As a result of such enormous numbers, microorganisms are essential components of the earth's biota and represent a large unexplored reservoir of genetic diversity.

Microbes play a critical role in modulating global biogeochemical cycles and influence all lives on earth ${ }^{[8]}$. All organisms in the biosphere either directly or indirectly depend on microbial activities. An understanding of microbial dynamics and their interactions with biotic and abiotic factors is indispensable in bioremediation techniques, energy generation processes, and biotechnological industries like pharmaceuticals, food, chemical and mining.

The microbial treatment of hazardous waste is based primarily on the utilization of the natural degradative capabilities of microorganisms. These capabilities derive from the metabolic diversity of both bacteria and fungi evolved from their role in the biochemical cycling of organic and inorganic compounds in the environment ${ }^{[9]}$. Many organic contaminants are subject to attack by microorganisms ${ }^{[10-12]}$. Biochemical pathways for some chemical classes are fairly well known such as alkanes, alkylbenzenes, surfactants, phenols and alcohol

Enzymes during normal metabolic functions of microorganisms facilitate biotransformation of organic contaminant. The advantages of biotransformation include complete mineralization of contaminants to innocuous products and the observation that microbe-mediated enzymatic reactions are generally faster than those of same reaction in the absence of microorganisms. Biotransformations are driven by the ultimate goal of increasing the size and mass of microbial populations. Microorganisms must transform environmentally available nutrients to forms that are useful for incorporation into cells and synthesis of cell polymers.

In this research, we provide an introduction and overview of the mathematical/mechanistic descriptions of important processes governing bioremediation, considering the critical factors of microbial processes (growth and decay of bacteria) and physical processes (advection and dispersion) as they relate to the applicability of bioremediation to the removal of organic pollutions from contaminated media $(1,3)$. Also the following treatment options were selected which include, crude oil-contaminated soil alone, crude oil-contaminated water, various percentage of nitrogen and phosphorous and heat-treated crude oil-contaminated water sample. All these treatment options were subjected to the same environmental conditions for a 56-day period.

\section{MATERIALS AND METHODS}

Sampling Site/Sample Collection: The sample for this study was crude oil-contaminated water. The sample was sourced from Bodo in Ogoniland, Gokana Local Government Area of Rivers State. The samples were collected using appropriate sterilized sampling containers. The samples were homogenized and transported to the laboratory to be processed.

Experimental Design: Crude oil-contaminated soil were sampled and seven treatment options designated as A, B, C, D, E, F and G were setup in triplicates in cells. Five (A-E) were biostimulated with $\mathrm{NH}_{4} \mathrm{NO}_{3}$ and $\mathrm{KH}_{2} \mathrm{PO}_{4}$ while unamended $(\mathrm{F})$ and heat treated $(\mathrm{G})$ served as control. The bioremediation investigation lasted for 56 days. The various treatment options and the controls were set up in triplicates in different cells using plastic bowls. For each treatment option, 2 Litre (wet weight) crude oil-contaminated water was amended with $40 \mathrm{~g}$ of treatment material according to Abu and Ogiji ${ }^{[13]}$. The (heat-treated) was autoclaved at $121^{\circ} \mathrm{C}$ for 15 minutes at $15 \mathrm{psi}^{[14-16]}$ 
Table 1: Experimental design and amendments

\begin{tabular}{|l|l|l|l|}
\hline $\begin{array}{l}\text { Cod } \\
\text { e }\end{array}$ & Treatment amended & $\begin{array}{l}\text { Treatment } \\
\text { Code }\end{array}$ & $\begin{array}{l}\text { Control } \\
\text { experiment } \\
\text { (unamended) }\end{array}$ \\
\hline A & $2 \mathrm{~L} \mathrm{CS}+40 \mathrm{~g}\left(2.5 \% \mathrm{~N}_{4} \mathrm{NO}_{3}+0.5 \% \mathrm{KH}_{2} \mathrm{PO}_{4}\right)$ & $\mathrm{F}$ & $2 \mathrm{~L} \mathrm{CS}$ only \\
\hline B & $2 \mathrm{~L} \mathrm{CS}+40 \mathrm{~g}\left(5 \% \mathrm{~N}_{4} \mathrm{NO}_{3}+1 \% \mathrm{KH}_{2} \mathrm{PO}_{4}\right)$ & $\mathrm{hG}$ & $2 \mathrm{~L} \mathrm{CS}+$ heating \\
\hline C & $2 \mathrm{~L} \mathrm{CS}+40 \mathrm{~g}\left(7.5 \% \mathrm{~N}_{4} \mathrm{NO}_{3}+1.5 \% \mathrm{KH}_{2} \mathrm{PO}_{4}\right)$ & & \\
\hline D & $2 \mathrm{~L} \mathrm{CS}+40 \mathrm{~g}\left(10 \% \mathrm{~N}_{4} \mathrm{NO}_{3}+2 \% \mathrm{KH}_{2} \mathrm{PO}_{4}\right)$ & & \\
\hline E. & $2 \mathrm{~L} \mathrm{CS}+40 \mathrm{~g}\left(12.5 \% \mathrm{~N}_{4} \mathrm{NO}_{3}+2.5 \% \mathrm{KH}_{2} \mathrm{PO}_{4}\right)$ & & \\
\hline
\end{tabular}

A:CS + $2.5 \%$ Nitrogen $(\mathrm{N})+0.5 \%$ Phosphorus $(\mathrm{P}) ; \mathbf{B}: \mathrm{CS}+5.0 \%$ Nitrogen $(\mathrm{N})+1.0 \%$ Phosphorus $(\mathrm{P}) ; \mathrm{C}: \mathrm{CS}+7.5 \%$ Nitrogen $(\mathrm{N})+1.5 \%$ Phosphorus $(\mathrm{P}) ; \mathrm{D}: \mathrm{CS}+10.0 \%$ Nitrogen $(\mathrm{N})+2.0 \%$ Phosphorus $(\mathrm{P}) ; \mathbf{E}: \quad \mathrm{CS}+12.5 \%$ Nitrogen $(\mathrm{N})+2.5 \%$ Phosphorus $(\mathrm{P}) ; \mathbf{F}$ : Contaminated sample (CS) only;G: Head-treated control

In each treatment, parameters such hydrocarbon-utilizing fungal count, total fungal count, total organic carbon, total nitrogen, total phosphorous and hydrocarbon level (TPH) were determined. Before the application of treatment materials, there was pretreatment analysis of the test samples (crude oilcontaminated water) using the protocols listed above. This was done to establish baseline data of the samples.

In monitoring the conditions and bioremediation process in each set up, little quantities of different treatment options and the controls were collected and analyzed for total petroleum hydrocarbon (TPH) and polycyclic aromatic hydrocarbon (PAH), total nitrogen, total phosphorous and microbial population on day zero and subsequent analysis were carried out throughout the duration (56-day) of the study ${ }^{[7]}$.

Statistical Analysis of Data: Statistical analysis was carried out on the data generated from the fungal counts and hydrocarbon concentrations for the different treatments using analysis of variance (ANOVA) and Duncan Multiple Comparison test, to test for the significant difference between the various treatment options at $95 \%(\mathrm{p}<0.05)$ confidence level.

Quality Assurance and Quality Control (QA/QC): Triplicate set up and duplicate analysis was done to check precision and accuracy while blank analysis was done to check contamination. Calibrations of instruments were carried out to check sensitivity and precision of instruments. The Outliers test was to check systematic errors which include methodic, instrument and/or personal errors.

Enumeration/identification of total fungal count (TFC) and hydrocarbon utilizing fungi (HUF): Counts for TFC and HUF were carried out on baseline sample, on day zero, 14, 28, 42 and 56 respectively. From each treatment option and control, $1 \mathrm{ml}$ (wet weight) of crude oil-contaminated water was homogenized in $9 \mathrm{ml}$ of $0.85 \%$ of normal saline in tenfold serial dilution. Dilutions (tenfold) of the suspensions were plated out in duplicate on saburoud dextrose agar (Titan biotech ltd) and incubated at $30^{\circ} \mathrm{C}$ for $2-3$ days for the TFC counts. For HUF counts, appropriate dilutions were selected and plated out in duplicate on mineral salt medium (MSA) of ${ }^{[17,18] .}$ Hydrocarbons were supplied through the mechanism of vapour phase transfer to hydrocarbon utilizing fungi by placing sterile Whatman No. 1 filter paper saturated with sterile crude oil and aseptically placed on the surface of the lid of the inverted Petri dishes. The plates were incubated at $30^{\circ} \mathrm{C}$ for 7 days. Individual's colonies of the hydrocarbon 
utilizing fungal were examined for cultural characteristics and were picked out and subcultured for biochemical test ${ }^{[17.18]}$. Fungal isolates were examined macroscopically and microscopically using the needle mounts method. A wet mount slide was made by transferring a small amount of the culture with a dissecting needle to a drop of lactophenol cotton blue stain on a grease-free clean glass slide, covered with a cover glass and examined under low power objectives. The isolate were identified according to Malloch (19). The reductions of TPHs was analysed on each sampling day using gas chromatograph with flame ionizing detector (GC-FID).

\section{RESULTS}

Baseline Characteristics of Crude Oil-contaminated Water: The values of the baseline fungal (total fungal count (TFC) and hydrocarbon utilizing fungi (HUF), physicochemical parameters (Total nitrogen, nitrate, total phosphorous, phosphate and total organic contents), gas chromatographic analysis of total petroleum hydrocarbons (TPH) as well as the heavy metal contents in the crude oilcontaminated water sample are presented in Table 2. The fungal counts (for total fungal (TFC) and hydrocarbon utilizing fungal (HUF) differs $10^{8} \mathrm{cfu} / \mathrm{ml}$ and $10^{7} \mathrm{cfu} / \mathrm{ml}$ respectively. This was indicative of the fact that the fungal populations making up the TFC and HUF were capable of utilizing petroleum hydrocarbons. The concentrations of the TPH in the crude oil-contaminated water also showed that there is active fungal population in the crude oil-contaminated water. This fungal population uses the hydrocarbons in the crude oil-contaminated water as source of carbon and energy owing to their low concentration in this crude oil-contaminated water that had high level of petroleum hydrocarbons. The baseline hydrocarbon contents in the crude oil-contaminated water before bioremediation were76.62 $\mathrm{mg} / \mathrm{kg}$ TPH but this was spiked with crude oil until $650 \mathrm{mg} / \mathrm{kg} \mathrm{TPH}$.

Table 2: Baseline Characteristics of Contaminated Media: Water

\begin{tabular}{|l|c|}
\hline Parameter & Mean value \\
\hline Total Heterotrophic Bacterial Count $\left(\mathrm{x} \mathrm{10} 0^{2} \mathrm{cfu} / \mathrm{ml}\right)$ & 19.00 \\
\hline Total Fungal Count $(\mathrm{TFC})\left(\mathrm{x} 10^{2} \mathrm{cfu} / \mathrm{ml}\right)$ & 3.00 \\
\hline Hydrocarbon Utilizing Bacterial $(\mathrm{HUB})\left(\mathrm{x} \mathrm{10} 0^{1} \mathrm{cfu} / \mathrm{ml}\right)$ & 7.00 \\
\hline Hydrocarbon Utilizing Fungal $(\mathrm{HUF})\left(\mathrm{x} 10^{1} \mathrm{cfu} / \mathrm{ml}\right)$ & 5.00 \\
\hline Total Nitrogen $(\%)$ & 13.73 \\
\hline Nitrate $(\mathrm{mg} / \mathrm{L})$ & 2.99 \\
\hline Total Phosphorous $(\%)$ & 0.84 \\
\hline Phosphate $(\%)$ & 2.58 \\
\hline Total Organic Content $(\mathrm{TOC})(\%)$ & 270.00 \\
\hline Total Petroleum Hydrocarbon $(\mathrm{TPH})(\mathrm{mg} / \mathrm{L})$ & 76.62 \\
\hline Polycyclic Aromatic Hydrocarbon $(\mathrm{PAH})(\mathrm{mg} / \mathrm{L})$ & - \\
\hline Cadmium $(\mathrm{mg} / \mathrm{L})$ & $<0.001$ \\
\hline Chromium $(\mathrm{mg} / \mathrm{L})$ & $<0.001$ \\
\hline Lead $(\mathrm{mg} / \mathrm{L})$ & $<0.001$ \\
\hline
\end{tabular}

Fungal counts and hydrocarbon breakdown in microbial remediation: The result of total fungal counts for crude oil-contaminated water were presented in figure 1 which shows that treatment option EW had the highest TF count $\left(2.99 \times 10^{8} \mathrm{Cfu} / \mathrm{ml}\right)$ for water on day 28 . However, FW had the lowest count $\left(1.5 \times 10^{3} \mathrm{Cfu} / \mathrm{ml}\right)$ for water on day 0 . However, FW had no growth from day 42 to day 56 . There 
was a general decrease for all amended options and for all other unamended which were A, B, C, D, E, $\mathrm{F}$ and $\mathrm{G}$ that decreased from $10^{8} \mathrm{cfu} / \mathrm{ml}$ by day 28 to $10^{3} \mathrm{cfu} / \mathrm{ml}$ by day 56 when the experiment ended. Control hG had no fungal growth on day 0 but had few insignificant fungal on day 42 and 56 . This is presented in Figure 1. The TFC counts were not statistically significant at $\mathrm{P}<0.05$ using ANOVA.

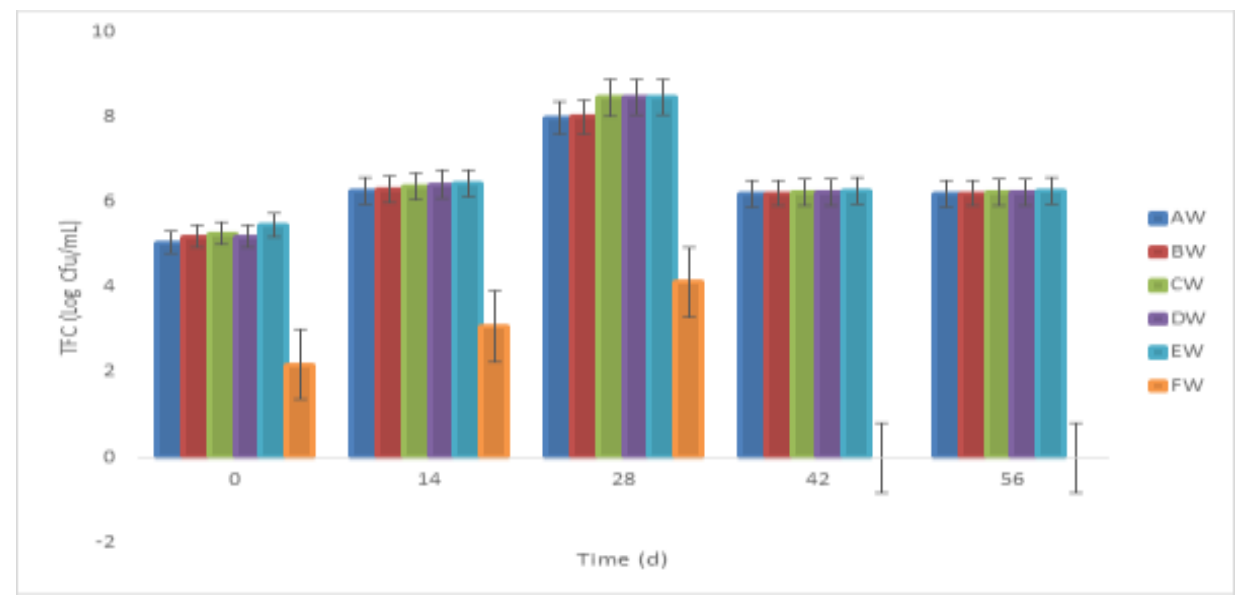

Fig.1: TF Profile during Bioremediation for Crude Oil- contaminated Water

Hydrocarbon utilizing fungal (HUF) count revealed that EW had the highest count $\left(6.35 \times 10^{7} \mathrm{Cfu} / \mathrm{ml}\right)$ for water on day 28 while FW had lowest count $4.0 \times 10^{2} \mathrm{Cfu} / \mathrm{ml}$ on day 0 . However, FW had no growth from day 42 to day 56. These were presented in Figures 2.

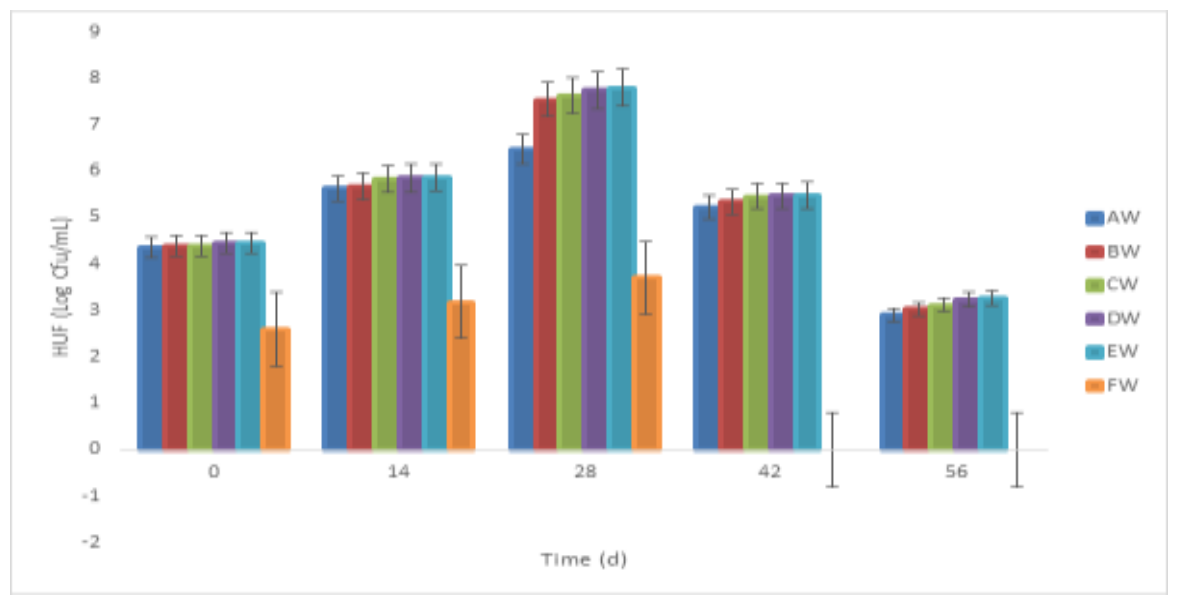

Fig.2: HUF Profile during Bioremediation for Crude Oil-contaminated Water

Microbial degradation of total petroleum hydrocarbons: The result of total petroleum hydrocarbon for crude oil-contaminated water was presented in figure 3. For all the treatment options on day 0 , the total petroleum hydrocarbons (TPH) range from 341.96 to $650.98 \mathrm{mg} / \mathrm{L}$ for crude oil-contaminated water. By day 56, the TPH of crude oil-contaminated water in all the treatment options were reduce to $<61 \mathrm{mg} / \mathrm{L}$. The percentage loss of TPH of various treatment options by day 56 as measured with GCFID were AW (83 \%), BW (88 \%), CW (90\%), DW (89 \%), EW (87\%), FW (60\%) and heat treated GW $(10 \%)$. This is presented in table 3. 


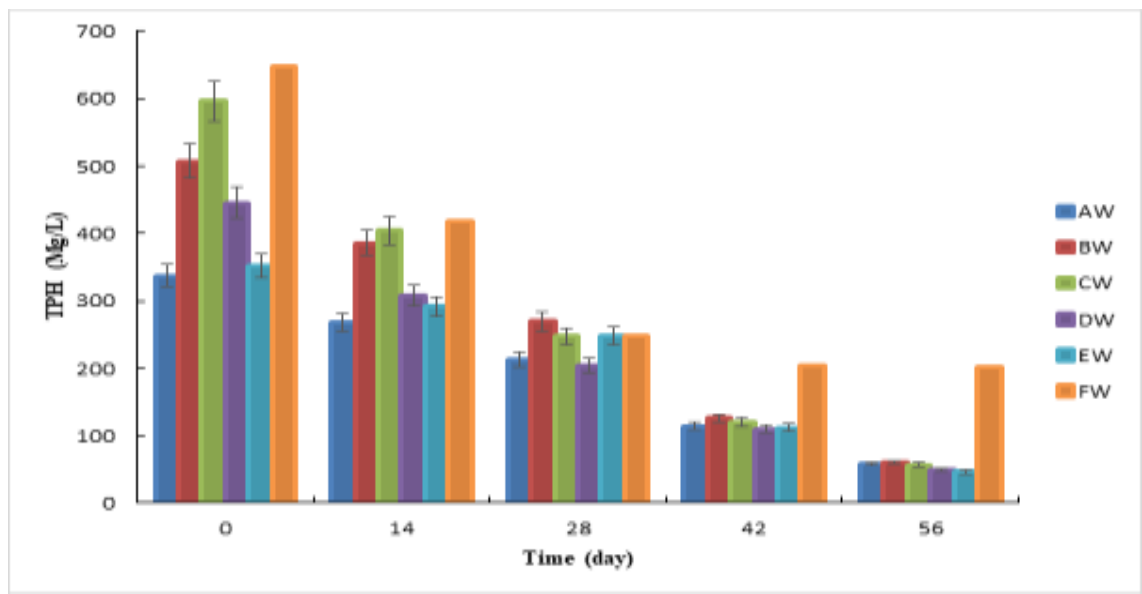

Fig.3: TPH Content during Bioremediation Crude Oil-contaminated Water

Table 3: Frequency of occurrence for fungal genera from crude oil-contaminated water

\begin{tabular}{lll}
\hline organisms & Frequency of occurrence & $\begin{array}{l}\text { Percentages frequency of } \\
\text { occurrence }\end{array}$ \\
\hline Cadida $\mathrm{sp}$ & 48 & 44.86 \\
Aspergillus $\mathrm{sp}$ & 15 & 14.02 \\
Rhodotorula $\mathrm{sp}$ & 3 & 2.80 \\
Nocardia $\mathrm{sp}$ & 2 & 1.87 \\
Scopulariopsis $\mathrm{sp}$ & 2 & 1.87 \\
Exophiala $\mathrm{sp}$ & 3 & 2.80 \\
Trichophyton $\mathrm{sp}$ & 3 & 2.80 \\
Microsporium $\mathrm{sp}$ & 4 & 3.74 \\
Phoma sp & 2 & 1.87 \\
Fonsecaea $\mathrm{sp}$ & 4 & 3.74 \\
Chaetimium $\mathrm{sp}$ & 4 & 3.74 \\
Penicillium $\mathrm{sp}$ & 4 & 3.74 \\
Cokeromyces $\mathrm{sp}$ & 2 & 1.87 \\
unidentified & 8 & 7.48 \\
Total & 107 & 99.99 \\
\hline
\end{tabular}

Characterization of fungal isolates: The fungal isolates from crude oil-contaminated water were characterized using the cultural characteristics, cell and colonial morphology/microscopy. A total of 107 hydrocarbon utilizing fungi were obtained from crude oil-contaminated water, ninety-nine (99) of which were assigned tentative identities and belonged to various genera which include Candida, Aspergillus, Fusarium, Penicilium, Rhodotorula, Microsporium, Trichophyton. . Eight fungal isolates could not be given tentative identities and were designated unidentified fungal isolates. Frequency of occurrence appeared as follows: Cadida sp (44.86\%), Aspergillus sp (14.02\%), Rhodotorula sp (2.80 $\%)$, Nocardia sp (1.87\%), Scopulariopsis sp (1.87\%), Exophiala sp (2.80\%), Trichophyton sp (2.80 $\%)$, Microsporium sp (3.74 \%), Phoma sp (1.87\%) Fonsecaea sp (3.74 \%), Chaetimium sp (3.74\%), Penicillium sp (3.74 \%), Cokeromyces sp (1.87\%) and unidentified isolates (7.48 \%). The frequency of occurrence of the fungi genera identified in the study and percentage loss of TPH is given in Table 3 and 4 respectively. 
Table 4: Percentage loss of TPH in crude oil-contaminated water

\begin{tabular}{|c|c|}
\hline Sample code & Percentage loss TPH (\%) \\
\hline AW & 83 \\
\hline BW & 88 \\
\hline CW & 90 \\
\hline DW & 89 \\
\hline EW & 87 \\
\hline FW & 60 \\
\hline GW & 10 \\
\hline
\end{tabular}

Mathematical Modeling of fungi in microbial remediation: The result of regression model of microbiological parameters was done using Statistical Package for Social Sciences (SPSS 23) for descriptive statistics while Econometric view (E-view 10) software was used for the pooled regression model. The result revealed the effect of variables such as time (T), nitrogen (TN) and phosphorous (TP) on microbiological parameters and the effect of microbiological parameters (THBC, TFC, HUB and HUF) on physicochemical variables.

Table 5: Model for Fungi Showing the Effect of Time, TN and TP on Microbiological Parameters for crude oil-contaminated Water that underwent bioremediation

\begin{tabular}{|c|c|c|c|c|c|c|c|c|}
\hline $\begin{array}{l}\text { Variables } \\
\text { TFCw }\end{array}$ & $\begin{array}{l}\hat{\beta}_{0} \\
\text { constant }\end{array}$ & $\begin{array}{l}\hat{\beta}_{1} \\
\text { Time }\end{array}$ & $\begin{array}{l}\hat{\beta}_{2} \\
\text { TN }\end{array}$ & $\begin{array}{l}\hat{\beta}_{3} \\
\mathrm{TP}\end{array}$ & \multirow[t]{5}{*}{$\begin{array}{l}\mathbf{R}^{2} \\
0.54\end{array}$} & \multirow[t]{5}{*}{$\begin{array}{l}\mathbf{R}_{\mathbf{a d j}} \\
0.52\end{array}$} & \multirow[t]{5}{*}{$\begin{array}{l}\mathbf{F}_{\text {cal. }} \\
41.48\end{array}$} & \multirow[t]{5}{*}{$\begin{array}{l}\text { Fprob. } \\
0.0000\end{array}$} \\
\hline Parameters & 2.7330 & 0.0503 & -0.1064 & 1.0214 & & & & \\
\hline Std Error & 0.6614 & 0.0113 & 0.0412 & 0.1119 & & & & \\
\hline t-value & 4.1321 & 4.4486 & -2.5802 & 9.1276 & & & & \\
\hline $\mathrm{P}$-value & 0.0001 & 0.0000 & 0.0112 & 0.0000 & & & & \\
\hline \multicolumn{9}{|l|}{ HUFw } \\
\hline Parameters & 3.6743 & 0.0119 & -0.1264 & 0.8568 & \multirow{4}{*}{0.33} & \multirow{4}{*}{0.31} & \multirow{4}{*}{17.41} & \multirow{4}{*}{0.0000} \\
\hline Std Error & 0.8099 & 0.0138 & 0.0505 & 0.1370 & & & & \\
\hline t-value & 4.5364 & 0.8631 & -2.5031 & 6.2521 & & & & \\
\hline P-value & 0.0000 & 0.3900 & 0.0138 & 0.0000 & & & & \\
\hline
\end{tabular}

$\hat{\beta}_{0}=$ Constant, $\hat{\beta}_{1}=$ Time, $\hat{\beta}_{2}=$ Total Nitrogen and $\hat{\beta}_{3}=$ Total Phosphorus

Table 5 shows regression model of total fungi count (TFC) and hydrocarbon utilizing fungi (HUF) of microbiological parameters and time for crude oil-contaminated water. The value of constant when the effect of $\mathrm{T}, \mathrm{TN}$ and TP was not considered for (TFC) was 2.7330. Time and total phosphorous affected TFC positively while total nitrogen affected TFC negatively. A unit increase in time increased TFC by 0.0503 while an increase in total phosphorous increased TFC by 1.0214. But an increase in total nitrogen decreased TFC by 0.1064 . 
When the effect of time, total nitrogen and total phosphorous were not considered (constant), hydrocarbon utilizing fungi (HUF) was 3.6743. Time and total phosphorous affected HUF positively while total nitrogen affected HUF negatively. An increase of time and total phosphorous increased HUF by 0.0119 and 0.8568 respectively. But a unit increase in total nitrogen decreased HUF by 0.1264 .

\section{DISCUSSION}

Crude oil-contaminated media (soil and water) were sampled and seven treatment options designated as A, B, C, D, E, F and G were setup in triplicates in cells. This experimental design was adopted with slight modifications from ${ }^{[16,17]}$ for crude oil-contaminated water. Five (A-E) were biostimulated with ammonium nitrate $\left(\mathrm{NH}_{4} \mathrm{NO}_{3}\right)$ and potassium dihydrogen phosphate $\left(\mathrm{KH}_{2} \mathrm{PO}_{4}\right)$ while unamended $(\mathrm{F})$ and heat treated $(\mathrm{G})$ were controls. The bioremediation investigation lasted for 56 days with $50 \%$ contaminated media amended with $1 \%$ treatment material (ratio 50:1). For each treatment options, 2 $\mathrm{kg}$ (wet weight) crude oil-contaminated water was amended with $40 \mathrm{~g}$ of treatment material. This nutrient amendment is in agreement with work of ${ }^{[13-16]}$. Total fungal counts (TFC), hydrocarbon utilizing fungi (HUF), physicochemical parameters, as well as gas chromatographic analysis were carried out on the nutrient amended and control samples over a 56 day period as the experiment progressed. The FW (unamended control for natural attenuation) was composed of the crude oilcontaminated water and indigenous fungi only while the heat-treated GW were sterilized using autoclave to monitor the effect of environmental factors during bioremediation $(20,16)$. The result of total fungal counts for crude oil-contaminated water were presented in figure 1 which showed that the treatment option EW had the highest TF count $\left(2.99 \times 10^{8} \mathrm{Cfu} / \mathrm{ml}\right)$ on day 28 . However, FW had the lowest count $\left(1.5 \times 10^{3} \mathrm{Cfu} / \mathrm{ml}\right)$ on day 0 . There was general increase in count for all treatments options which increased from $10^{5} \mathrm{Cfu} / \mathrm{ml}$ on day 0 to $10^{8} \mathrm{Cfu} / \mathrm{ml}$ on day 28 and it decreased from $10^{8} \mathrm{cfu} / \mathrm{ml}$ by day 28 to $10^{4} \mathrm{cfu} / \mathrm{ml}$ by day 56 when the experiment ended. Control hG had no bacterial growth on day 0 but had little insignificant bacterial growth on day 42 and 56 . The heat-treated control hG showed no growth for TFC and HUF on day 0, 14, 28, 42 but an insignificant growth on day 56. From the result, it was clear that the indigenous fungi in the crude oil-contaminated water were already acclimatized to hydrocarbons since there was also loss of TPH in the control as bioremediation progressed. Ibekwe and Okpokwasili, ${ }^{[15]}$ Chikere et al.,${ }^{[19]}$, Odokuma and Dickson ${ }^{[20]}$, observed similar results.

For all the treatments options on day 0 , the total petroleum hydrocarbon (TPH) ranged from 341.96 to $650.98 \mathrm{mg} / \mathrm{L}$. In all the treatment options by day 56 , the TPH was $<61 \mathrm{mg} / \mathrm{L}$. The TPH of crude oilcontaminated water (AW) decreased from an initial value of $337.61 \mathrm{mg} / \mathrm{L}$ on day 0 to $58.23 \mathrm{mg} / \mathrm{L}$ on day 56 while BW decreased from $506.61 \mathrm{mg} / \mathrm{L}$ on day 0 to $60.46 \mathrm{mg} / \mathrm{L}$ on day 56 . The TPH decreased from $596.60 \mathrm{mg} / \mathrm{L}$ on day 0 to $57.11 \mathrm{mg} / \mathrm{L}$ on day 56 for treatment $\mathrm{CW}$ while $\mathrm{DW}$ decreased from $445.72 \mathrm{mg} / \mathrm{L}$ on day 0 to $49.25 \mathrm{mg} / \mathrm{L}$ on day 56 . For ES EW, the TPH decreased from $352.37 \mathrm{mg} / \mathrm{L}$ on day 0 to $46.36 \mathrm{mg} / \mathrm{L}$ on day 56 . The TPH of FW that underwent natural attenuation decreased from initial value of $647.88 \mathrm{mg} / \mathrm{L}$ on day 0 to $201.55 \mathrm{mg} / \mathrm{L}$ on day 56 while the heat-treated control GW decreased from $539.82 \mathrm{mg} / \mathrm{L}$ on day 0 to $484.55 \mathrm{mg} / \mathrm{L}$ on day 56 . The TPH of the amended were significantly different from the TPH of unamended and heat-treated at 95\% confidence interval (P < 0.05 ) but were not significantly different to one another. The unamended control (FW) contained populations of crude oil degrading fungi which increased with time with the depletion of hydrocarbons proving that indigenous fungal communities in the hydrocarbon impacted- water have the natural capacity to degrade TPHs since they could use crude oil components as a source of carbon and energy. This finding is in agreement with the report of Chikere et al. ${ }^{[19]}$ in bioreactor-based bioremediation oilpolluted marine sediment. Also Ibekwe and Okpokwasili ${ }^{[15]}$, observed similar trend in bacterial treatment of drill cuttings. 
The modeling of the physicochemical and microbiological parameters was done using Statistical Package for Social Sciences (SPSS 23) for descriptive statistics while Econometric view (E-view 10) software was used for the pooled regression model and Microsoft Excel was used for all the plots.

The result of regression model of total fungal count (TFC) and hydrocarbon utilizing fungi showing the effect of variables such as time (T), nitrogen (TN) and phosphorous (TP) on microbiological parameters and the effect of microbiological parameters on physicochemical variables. Time and total phosphorous affected TFC positively while total nitrogen affected TFC negatively. A unit increase in time increased TFC by 0.0503 while an increase in total phosphorous increased TFC by 1.0214 . But an increase in total nitrogen decreased TFC by 0.1064 . These increases and decreases were significant at p-value $<0.05$ and t-values 4.4486, -2.5802 and 9.1276. For crude oil-contaminated water under study, the effect of time, nitrogen source and phosphorous source accounted for $54 \%$ of the total changes observed in TFC and the remaining $46 \%$ came from variables not included in the model. The F value (41.48) is an indication of the expression of overall model which was significant at $\mathrm{p}-$ value $<0.05$. Montgomery $e t$ $a l^{[21]}$ and Harvey and Harvey and Author Author ${ }^{[3]}$ stated that any approach to modeling the relationship between a dependent variable $\mathrm{Y}$ and one or more independent variables denoted $\mathrm{X}$, such that the model depends linearly on the unknown parameters to be estimated from the data.

For HUF, time and total phosphorous affected HUF positively while total nitrogen affected HUF negatively. An increase of time and phosphorous source increased HUF by 0.0119 and 0.8568 respectively. But a unit increase in nitrogen source decreased HUF by 0.1264 . These values were significant at $\mathrm{p}$-value $<0.05$ and t-values -2.5031 and 6.2521 respectively except time which was not significant at p-value $(0.3900)>0.05$. The changes observed from the effect of time, total nitrogen and total phosphorous on HUF accounted for $33 \%$ of the total changes while $67 \%$ came from variables not included in the model. The overall model was significant at $\mathrm{p}$-value $<0.05$ with $\mathrm{F}$ value 17.41. HUF affected TOC positively while TFC and time affected TOC negatively. A unit increase in time and TFC decreased TOC while a decrease in TOC increased HUF. Time and TFC affected TPH negatively while HUF affected TPH positively. A unit increase in time and TFC decreased TPH. A decrease in TPH increased HUF. Montgomery et al ${ }^{[21]}$ and Harvey and Author ${ }^{[3]}$ stated that any approach to modeling the relationship between a dependent variable $\mathrm{Y}$ and one or more independent variables denoted $\mathrm{X}$, such that the model depends linearly on the unknown parameters to be estimated from the data.These models have established that adjusting of limiting nutrients (N, P) is the key to effective and efficient bioremediation of crude oil-contaminated soil.

\section{CONCLUSIONS}

- $\quad$ The concentration of the toxicant-TPH was reduced below acceptable limit which suggest that the technology was effective.

- $\quad$ Different experimental setup showed varying degrees of remediation with $\mathrm{CW}$ being the most efficient and effective.

- $\quad$ Environmental factors also played a role in the remediation as shown by heat-treated setup.

- $\quad$ Crude oil-contaminated water only (FW), if left for natural attenuation will take a longer time to degrade hence the need for bioremediation.

- $\quad$ The global problem of crude oil-contaminated water is what this study has proffered solution to, through bioremediation technology and mathematical model. 
- It is important to increase phosphorous and reduce nitrogen for water bioremediation so as to have biomass boast.

- $\quad$ Adjusting of limiting nutrients (nitrogen, phosphorous) is the key to effective and efficient bioremediation of crude oil-contaminated media.

\section{REFERENCES}

1. R.Atlas and J.Philip, Bioremediation: Applied Microbial Solutions for Rea World Environmental Cleanup. American Society for Microbiology (ASM) Press, Washington, 2005,DC, pp.78 - 105.

2. Christian, Analytical Chemistry. Sixth edition, John Wiley and sons Inc. Singapore,2004.

3. M. Harvey and C.Author, Fitting Models to Biological Data using Linear and Non Linear Regression. A practical guide to curve to fitting. GraphPad Software Inc., San Diego CA,2003, www.graphpad.com.

4. B.M.Chen and H.V.Kojouharov, Mathematics modeling of trichloroethylene in aquifers. Computer mathematics applied journal,2008, 56:645 - 656 .

5. G.E.P. Box and G.M.Jenkins and G.C.Reinsel, Time Series Analysis: Forecasting and Control, $3^{\text {rd }}$ edition. Prentice Hall, Englewood Cliffs, New Jersey,1994.

6. W.B.Whitman, D.C. Coleman, W.J. Wiebe, Prokaryotes: the unseen majority. Process Natural Academy of Science USA.1998, 95: 6578 - 6583.

7. B.K.Singh, C.D. Campbell, S.J. Sorenson, J. Zhou, Soil genomics. Nature Reviews Microbiology.2009, 7:756 doi: 10.1038/nrmicro2119-c1.

8. P.Garbeva, J.A. van Veen, J. D. van Elsas, Microbial diversity in soil: selected microbial populations by plant and soil type and implications for disease supressiveness. Annual Review Phytopathology,2004 42: $243-270$.

9. A.J.Weightman and J.H.Slater, The Problems: Xenobiotics and recalcitrance. In: Microorganisms in Action: Concepts and Application in Microbial Ecology. Lynch, J. M. and Hobbie, J. E. (eds). Blackwell Scientific Publications, London.1988,Pp.322 - 347.

10. M.A.Alexander, Introduction to Soil Microbiology, 2nd ed. John Wiley and Sons, NewYork, 1985.

11. R.M.Atlas, Microbial degradation of petroleum hydrocarbon: An environmental perspective. Microbiological Review, 1981, 45: 180-209

12. H.Kobayashi and B.E.Rittman, Microbial removal of hazardous organic compounds, 1982,

13. G.O. Abu and P.A.Ogiji, Initial test of a bioremediation scheme for the cleanup of an oil-polluted water body in a rural community in Nigeria.Bioresouces Technology,1996, 58:7 - 12.

14. L.O.Odokuma and M.N.Ibor, Nitrogen fixing bacteria enhanced bioremediation of a crude oil polluted soil. Global Journal of Pure and Applied Science,2002, 8: 455 - 468.

15. S.E.Ibekwe and G.C.Okpokwasili, Bacterial treatment of drill cuttings.International journal of environmental bioremediation and biodegradation, 2016,4(1):13 - 20. Dio: 10.12691

16. A.L. Mills, C. Breuil and R.R.Colwell, Enumeration of petroleum-minerals in the world ocean. DeepSea Research.1978, 15: 433 - 459.

17. G.C. Okpokwasili and B.B.Okorie, Biodegradation potentials of microorganisms isolated from car engine lubricating oil. Tribology International,1988, 21: 215 - 220.

18. 19 Malloch, D. (1981). Moulds: Their isolation, cultivation and identification. University of Toronto Press, London. 
19. B.C. Chikere, G.C. Okpokwasili and B.O.Chikere, Monitoring of microbial hydrocarbon remediation in the soil. Biotechnology,2011,. 1(3): $117-138$.

20. L.O.Odokuma and A.A.Dickson, Bioremediation of a crude oil-polluted tropical rainforest soil. Global Journal of Environmental Science. 2003,2: 29 - 40.

21. D.C.Montgomery, E.A. Peck and G.G.Vining, Introduction to linear regression analysis; $3^{\text {rd }}$ edition, John Willey \& Sons, New York, 2001.

\section{* Corresponding Author: Dr. Ibekwe, S.E,}

Department of Microbiology,University of Port Harcourt, P.M.B. 5323,

Port Harcourt,Nigeria

Date of publication on line 26.10.2020 